\title{
Article \\ Counteracting Overtourism Using Demarketing Tools: A Logit Analysis Based on Existing Literature
}

\author{
Umut Gülşen, Hüseyin Yolcu, Pelin Ataker, İlke Erçakar and Sevil Acar *(D) \\ Department of Tourism Administration, Boğaziçi University, 34342 Istanbul, Turkey; \\ umutgulsen18@gmail.com (U.G.); huseyinyolcu97@hotmail.com (H.Y.); atakerpelin@gmail.com (P.A.); \\ ilkeercakar98@gmail.com (İ.E.) \\ * Correspondence: sevil.acar@boun.edu.tr; Tel.: +90-212-359-7182
}

Citation: Gülşen, U.; Yolcu, H.;

Ataker, P.; Erçakar, İ.; Acar, S.

Counteracting Overtourism Using

Demarketing Tools: A Logit Analysis Based on Existing Literature.

Sustainability 2021, 13, 10592. https://

doi.org/10.3390/su131910592

Academic Editor: María

García-Hernández

Received: 27 August 2021

Accepted: 21 September 2021

Published: 24 September 2021

Publisher's Note: MDPI stays neutral with regard to jurisdictional claims in published maps and institutional affiliations.

Copyright: (c) 2021 by the authors. Licensee MDPI, Basel, Switzerland. This article is an open access article distributed under the terms and conditions of the Creative Commons Attribution (CC BY) license (https:// creativecommons.org/licenses/by/ $4.0 /)$.

\begin{abstract}
Over the past few decades, demarketing has come up as an unorthodox but potentially strong approach that can be used to counter the negative effects of oversaturation in tourism destinations. This study investigates the difference that demarketing strategies can make on mitigation efforts towards overtourism in destinations across the globe by conducting a meta-analysis of the previous literature examining various case studies on the topic. This study approaches demarketing efforts against overtourism through the lens of the 4Ps of marketing: price, place, product, and promotion. The results of the logit model designate price as the only significant predictor in the mitigation of overtourism through demarketing, with the other three falling short. The findings are enhanced through various other predictors from the literature as well as government effectiveness in the destinations. Moreover, the driving forces such as environmental concerns and community satisfaction have proven to be significant factors as well.
\end{abstract}

Keywords: demarketing; overtourism; sustainable tourism; logit model

\section{Introduction}

Over the past few decades, tourism has become a rapidly and steadily growing sector with developing technologies and ease of transportation. However, this growth and intense touristic activities have also resulted in lasting negative effects. It is an inevitable fact that these adverse impacts will continue to grow similar to an avalanche unless relevant precautions are taken. As the side effects of tourism have started to become more and more evident, the concept of overtourism became increasingly widespread amongst experts. Consequently, it has become a popular topic that has attracted the attention of researchers.

According to Dodds and Butler [1], overtourism is a phenomenon that occurs when a very large influx of visitors at a destination causes various negative consequences in that particular space. The intensity of the tourist influx mentioned in the definition certainly differs for each destination; therefore, a number of factors are used to determine excess visitor levels such as carrying capacity, environmental degradation, and local satisfaction. Tourism provides various tools and rationales for the maintenance of cultural and natural heritage throughout the world. Issues such as the conservation and rehabilitation of historical and natural attractions have been the main areas of interest for tourism. On the other hand, the unplanned growth of the sector, mismanagement, and an intense influx of visitors cause significant damage [2]. Therefore, as a rapidly and continuously growing sector, tourism needs to be carefully managed against the growing economy and the challenges it faces.

Recently, sustainable tourism has been heralded as the best approach to leaving destinations intact for future generations. Butler [3] explains it as "tourism which is in a form which can maintain its viability in an area for an indefinite period of time". Sustainable tourism has become very important over the past few decades together with its three pillars (environmental, economic, and social sustainability). In terms of economic 
benefits, around 10 percent of the global GDP is generated by tourism directly or indirectly. For environmental effects, degradation is rising each passing day, and destinations are exceeding their carrying capacity and losing what makes them special. The destruction of destinations also causes problems for the locals, and most major tourist hotspots are full of unhappy locals, which causes many protests [3].

It can be said that there is overtourism in regions where environmental degradation is experienced due to an increase in the density of tourists, heavy traffic, and a decrease in the satisfaction of both the local people and visitors. In the last few decades, different approaches have been put forward as potential avenues dealing with overtourism. Among these are policies implemented such as tourism taxes that help mitigate overtourism, introducing supply side precautions such as spatial planning, reducing demand in peak periods, and demarketing. Demarketing is any attempt that is made to discourage consumers from a particular product/destination. The concept of demarketing was first used by Kotler and Levy [4], who defined the term as "that aspect of marketing that deals with discouraging customers in general or a certain class of customers in particular on either a temporary or permanent basis". To Bradley and Blythe [5], demarketing can be defined as the deliberate attempt by marketers to reduce demand for a product by using the same tools and techniques as normally used to increase demand. Demarketing seeks to reduce demand for a product: sometimes overall, sometimes from 'undesirable' customers, and sometimes at specific times.

As the concept of demarketing has evolved and gathered the attention of the scientific community at large, it is realized that demarketing has potential as a control mechanism for overtourism as well [6]. The research of Olokesusi et al. [7] indicates that demarketing is also an applicable solution in the tourism context to reduce excess utilization of the carrying capacity and to provide contributions to sustainability by enabling demand control. When it comes to applications in destinations, it can be said that demarketing is a group of strategies implemented to deter people from a location for a limited time or permanently.

Kotler and Levy [4]; Clements [8]; Gerstner, Hess, and Chu [9]; and Beeton and Pinge [10] all separated demarketing into three main categories: general, selective, and ostensible demarketing. General demarketing is a strategy to reduce total demand for all, which is applicable for situations such as shortages, overcapacity, or deliberate product elimination, where the supply demand balance is disturbed. This strategy has been implemented very successfully when foot and mouth disease appeared in the countryside of the UK, with the help of mass media publishing up-to-date information on the disease and the government placing restrictions and bans on many locations [11]. Selective demarketing can be seen as an inherent part of segmentation $[8,10]$ or competitive differentiation as it is used in order to discourage a certain target audience from the product. This method is used to target the most beneficial, attractive tourist segment for a destination to use its capacity in the best way while deterring the segment that is harmful or reducing the maximum benefit for the location. In the case of Cyprus, mass tourism groups were excluded and promotions targeting certain segmentations were made in order to remove young tourists who exhibit inappropriate behavior in the island and to attract high-income tourist groups to the island [12]. Finally, ostensible demarketing is an attempt to restrict the product's appeal by emphasizing the scarcity of the product. It normally has the opposite effect as the desire for exclusivity on the side of the consumers makes this effort counterproductive. However, ostensible demarketing has not been implemented for destinations yet.

Medway et al. [11] argue that there are four underlying reasons for a destination to resort to demarketing strategies. The most prominent of these reasons is the target of sustainability, and the implication is that people responsible for the management of overcrowded destinations may prefer reducing their visitor numbers to ensure long-term prosperity, even if there is a decrease in their profits. Another one is segmentation and targeting, as manipulating the image of a destination to appeal to a certain segment would work as a demarketing tool against other segments. Third, there is the reduction in the seasonality effect because destinations want to ensure a more regular supply of consumers 
rather than dips and spikes in numbers. Lastly, crisis management is put forward as a reason for demarketing destinations. Medway et al. [11] argue that, instead of using demarketing as a reactive tool to combat problems that have already occurred, some destinations may prefer to use it as a proactive strategy for preventing large-scale issues that may arise due to overtourism and disorder.

Demarketing tools can be categorized in various layers. Suh et al. [13] look at demarketing through the lens of a traditional marketing mix, making use of the 4Ps (price, place, product, and promotion) to underline how a destination (or a firm) can approach their consumers from different angles with differing strategies. They put forward examples of changing the conditions for the four marketing mix elements such as decreases in advertisements or reductions in promotion costs, all aimed towards making demarketing strategies effective for the user. As can be seen in Table 1, the suggested methods of Suh et al. [13] can be utilized for tourism just as well as for any other sector that utilizes marketing. They decided on this sort of categorization due to the fact that more empirical research on the topic was necessary and the that familiarity of the marketing mix would make it easier to group the tools under easily understandable headings.

Table 1. Example of demarketing tools categorized as $4 \mathrm{Ps}^{1}$.

\begin{tabular}{|c|c|c|c|}
\hline Price & Place & Product & Promotion \\
\hline $\begin{array}{l}\text { - Increasing the } \\
\text { related fees } \\
\text { - Increasing entry } \\
\text { prices }\end{array}$ & $\begin{array}{l}\text { - Reducing the field } \\
\text { of consumption } \\
\text { - Reducing the field } \\
\text { of distribution } \\
\text { - Putting restraints } \\
\text { on sales }\end{array}$ & $\begin{array}{l}\text { - Restricting the } \\
\text { utility of the product } \\
\text { - Increasing the } \\
\text { availability } \\
\text { of alternatives } \\
\text { - Highlighting the } \\
\text { damage factor of } \\
\text { the product } \\
\text { - Reducing the } \\
\text { attractiveness }\end{array}$ & $\begin{array}{c}\bullet \text { Reducing } \\
\text { advertisement field } \\
\text { - Adding mandatory } \\
\text { warning labels }\end{array}$ \\
\hline
\end{tabular}

${ }^{1}$ Note: Adapted from [13].

The current study departs from the identification of the overtourism problem in various destinations and makes use of the demarketing tools as possible explanatory factors for success or failure to mitigate overtourism in these destinations by synthesizing the findings of the previous literature. It explores each piece of the available literature in order to determine the factors that might have contributed to the solution or the deadlock of the overtourism problem. It is aimed at discovering whether demarketing can be an effective way of mitigating overtourism. For this purpose, the main research question is "What are the effective demarketing tools that help mitigate overtourism?", and a supporting research question would be "What does the previous literature tell us about the most effective tools to combat overtourism in various destinations?"

The motivation for addressing this particular issue is that overtourism is becoming an increasingly serious problem, and it causes long-lasting negative effects on both the environment and society. In this context, the public outcry in Barcelona, Spain, is a very noticeable example. The residents' cries to the government due to the problems experienced as a result of the excess number of tourists, their reproaches against tourists, and even hateful discourses reveal the severity of the problem. Therefore, this research is conducted with the motivation to find ways to reduce overtourism, and it claims that demarketing tools have the potential to positively affect destinations if applied properly.

The originality of the study arises from its approach that drains the main conclusions of relevant research from a variety of destinations on the effectiveness of the demarketing tools applied as well as on the dependence of overtourism mitigation on other factors such as environmental and community well-being concerns. Moreover, this is the first attempt to analyze the impact of government effectiveness at the national level on the success or failure to mitigate overtourism. 
A meta-analysis of the literature is undertaken based on the case studies on destinations where demarketing tools are used. To achieve this, the demarketing tools used in these destinations are categorized under the appropriate marketing principles and are analyzed to find out how effective they have been in mitigating overtourism in the destinations they were used. The flow of the paper is as follows: Section 2 introduces the data and the method that are utilized. Section 3 interprets the findings of the meta-analysis. Section 4 discusses the results, and finally, Section 5 concludes.

\section{Materials and Methods}

The aim of this study is to find out whether the demarketing strategies of the destinations coping with overtourism have been successful by making a meta-analysis of the relevant works of the literature. Briefly, meta-analysis is a source scanning method that systematically summarizes the results of studies on any subject. It is a form of systematic review that utilizes statistical methods and/or regression analysis to synthesize the findings of the relevant literature.

The data were gathered from articles, books, academic papers, and reports that were previously published. As such, not cases (in our case, destinations) but the literature investigating the cases are collected. Tourism Planning $\mathcal{E}$ Development, Tourism Management, Annals of Tourism Research, and Journal of Sustainable Tourism are among the journals where the reviewed articles were published. The rest of the studies come from national or international research reports, theses, conference proceedings, or books. Thirty different studies were reviewed, and sixty different case examples were collected to find out which demarketing practices were significant in mitigating the overtourism of destinations from different parts of the world (see Appendix A Table A1 for the papers and destinations in the data set). Full references to all of the examined papers are provided in the References section. While most of the papers focus on one destination at a time, twelve papers (such as Beeton \& Benfield (2002), which focuses on three destinations in the UK, Italy, and Australia, and Andriotis (2018), which focuses on two destinations in Brazil and Greece) undertook a detailed look at two or more destinations. As the aim was to cover as many destinations as possible, the distribution of the destinations is quite wide-ranging, covering all of the continents. The countries where the destinations belong to are as follows: Australia, Austria, Azerbaijan, Belgium, Bhutan, Botswana, Brazil, Canada, Chile, China, Croatia, Cyprus, the Czech Republic, Ecuador, Egypt, Estonia, Germany, Greece, Iceland, India, Indonesia, Ireland, Italy, Latvia, Lithuania, Luxembourg, Malta, Mexico, Myanmar, the Netherlands, New Zealand, Norway, Peru, Slovenia, Spain, Samoa, Sweden, the UK, the US, and Vanuatu.

"Demarketing", "overtourism", and "degrowth of tourism" were used as keywords in the search of the literature in Web of Science, Scopus, and Google Scholar. The literature analyzed refers to a wide typology of tourist destinations and resources (beaches, natural spaces, national parks, wildlife centers, and historic and archaeological sites, large cities, historic cities, etc.). The publication dates of the studies range from 1989 to 2021 (included). The cases where overtourism has been mitigated or not mitigated were analyzed. Since the dependent variable of concern was binary, a logit model was used to conduct the analysis. The logistic distribution constrains the estimated probabilities to lie between 0 and 1 . The change in probability is not constant (linear), with constant changes in the independent variables, $X$. This means that the probability of a success (the case that overtourism is mitigated) given the predictor variable $(X)$ is a non-linear function, specifically a logistic function. Logistic regression has the additional advantage that all of the predictors can be binary, a mixture of categorical and continuous, or just continuous [14].

The logit regression formula that is used is as follows:

$$
\text { Probability (event) }=\frac{1}{1+e^{-z}}
$$


where

$$
z=b 0+b 1 x 1+b 2 x 2+\ldots b p x p
$$

Equivalently, $z$ can be written as follows:

$$
\log [\operatorname{Prob}(\text { event }) / \operatorname{Prob}(\text { no event })]=b 0+b 1 x 1+b 2 \times 2+\ldots b p x p
$$

Probability (event) stands for the probability of mitigation of overtourism in our analysis; $x_{1}, x_{2}, \ldots x_{p}$ are the independent variables; and $b_{1}, b_{2}, \ldots b_{p}$ are the corresponding coefficients of the independent variables, which are all binary in our case.

The estimated coefficient of a categorical explanatory variable reflects the effect of a change in that variable from 0 to 1 on the dependent variable. If the coefficient is approximately zero or insignificant, it means that, when the dummy value of that variable for an observation unit moves from 0 to 1 , ceteris paribus, the probability of that unit to cause a decline in visitor numbers (i.e., mitigate overtourism) is about 0.5 . When the coefficient is positive (or negative), the probability is higher (lower) than 0.5.

As overtourism is a very serious issue that cannot be completely dealt with in the span of a few years (which is the timeline of basically all of the case studies that were used for this research), the research approach has been simplified in a way to infer whether "mitigation of overtourism" was achieved in the related destination not. It is determined by looking at one common characteristic that all of these destinations have: overcrowdingvisitor numbers exceeding the carrying capacity in a way that affects health and safety in the area. If the demarketing strategies and plans employed in these destinations caused either a decrease in the number of visitors or a decrease in the annual visitor growth for the destination, they are considered successful instances of overtourism mitigation. While failure to mitigate overtourism is coded as zero, success in mitigating overtourism is coded as one. The success is associated with a decrease in either the number of visitors or the growth of the number of visitors in the destination.

Nine independent variables are used to explain the probability of success in mitigating overtourism. Of those nine independent variables, four of them (the demarketing tools) constitute the core of this research, while the other five are supportive variables that are used in order to enhance our understanding of the overtourism problem using the literature findings.

Demarketing Tools: Departing from the work of Suh et al. [13], the demarketing tools are categorized under the 4P marketing principles: Place, Product, Promotion, and Price. These four variables are also coded as " 0 " or " 1 ", which represents whether they are used (1) or not (0) by destinations to overcome overtourism. For example, if only Price is used as a demarketing tool against overtourism in a destination, it is coded as " 1 " and the other demarketing tools are coded as " 0 ". It should also be pointed out that each tool is coded individually upon their presence and not grouped under an umbrella term such as "demarketing tools". In their article, Hall and Wood [6] posited that marketing strategies are used as a way to achieve demarketing and to decrease consumer interest. Hence, the 4Ps of marketing are applied in various forms as a tool of potentially mitigating overtourism. All of the destinations in our sample had at least one of the four core demarketing tools present among their mitigation efforts. For example, Price was used as a tool in the form of raising or introducing entrance fees, raising the cost for parking areas, or even putting a daily tourist tariff into motion in the case of Bhutan [15]. For Place, the go-to tool used for most destinations was the restriction of accessible areas, together with other strategies such as implementing zoning plans and, as in the case of Giza, limiting the roads that had access to the target space [2]. Of the other demarketing tools, Product was used in various ways such as putting time constraints on certain activities (or even completely shutting these activities down); implementing new policies and regulations to obtain a stricter grip on the situation; and restricting transport in the case of Bled, Slovenia [16]. Lastly, the measures used for demarketing as part of Promotion tended to consist of running information campaigns for both visitors and locals, outright reducing the number of 
advertisements present for the destination, focusing on select tourist groups in order to discourage others that are considered troublesome, and discouraging daytrips in the case of Napa Valley [17]. Considering the fact that nearly two thirds of the case studies that were looked into resulted in favorable (i.e., successful) outcomes in terms of mitigation, there is a high chance that at least one of these marketing elements might prove crucial for the success of demarketing strategies in destinations.

The other independent variables are as follows: Refereed, Environmental Concern, Community Satisfaction, Post-2012, and Government Effectiveness.

Refereed: Refereed studies are usually the ones that go more in-depth when researching any particular topic, and the extra oversight provided by the ones performing the peer reviews ensure the accuracy and comprehensiveness of the research. To that end, it is assumed that refereed studies have significantly different outcomes than those that were not. This also enables us to test the presence of a possible publication bias. In other words, the results reported in articles from refereed journals or books may not entirely be representative of the results of all of the research that has been conducted in a field [18]. With well over half of the studies that are analyzed being refereed, we expect that publications in refereed journals or books might be less eager to identify failures as success stories where destinations suffer from substantial overtourism. The case studies that were refereed were coded as " 1 ", while studies that were not refereed were coded as " 0 ".

Post-2012: This is a binary variable that uses the year 2012 as a cutoff point for the case studies that were performed before and after it. The year 2012 was chosen owing to the importance of the Rio +20 agenda. Additionally, known as The United Nations Conference on Sustainable Development, the Rio +20 was a major international gathering that hosted delegations from over one hundred and ninety countries to discuss the sustainability concerns of the countries at large. The reason why this conference is so important is because it affirmed and strengthened the commitments to Agenda 21, a global movement agenda agreed upon by the United Nations twenty years prior to the Rio +20 , in the first version of the conference in 1992, in order to increase worldwide efforts towards a more sustainable Earth. On top of reaffirmation of the aforementioned plan, a new document pledging support to the cause of sustainability was agreed upon, referred to as "The Future We Want". The positive conclusion of the conference and the renewed pledges by all $190+$ countries towards more sustainable practices should have meant that, going forward from 2012, governments would put significantly higher effort towards the preservation of the environment and the strengthening of policies in various areas of life - including tourism. Accordingly, it is not much of a stretch for us to pick 2012 as a cutoff point to see whether the promises of the Rio +20 have a significant effect on mitigating overtourism or if the delegates were just conforming to the methods of their predecessors from twenty years ago who did not follow through on their pledges and verbal commitments. The variable Post-2012 takes the value " 1 " if the case studies were conducted after 2012 and " 0 " otherwise.

Environmental Concern and Community Satisfaction: These two are the factors that were identified in the destinations where overtourism took place as possible concerns. This study aims to find out whether the existence of either of these two as driving forces for overtourism mitigation in the destinations was a factor that significantly affected the chances of success in the results of previous research on the topic. Half of the cases that are featured in this study have environmental concerns as an incentive to counteract overtourism. These concerns include issues such as the conservation of natural resources, dealing with threats to local fauna and flora diversity, protection of natural heritage sites, combating soil degradation, and preserving the Blue Flag status of the beaches as in the case of Playa de las Catedrales [19]. The threat that overtourism poses towards the stability and sustainability of the environment (as well as natural resources) is quite hard to ignore, and many destinations are being forced to take action against it one way or the other. Butler [3] argues that the consenting assistance of all related parties in a particular destination would 
be necessary to achieve sustainability, which is a main goal when dealing with overtourism. As for community satisfaction, it is hypothesized that, if the local population was unhappy and was putting a lot of pressure on the authorities to provide solutions for their location's overtourism problems, there would be a higher chance of the mitigation efforts being successful due to the pressure of locals-the same locals who elect those authorities. Every passing day, the outcry of local populations of destinations that suffer from overtourism become stronger, with the residents of some high profile cities, such as Barcelona, even developing cases of tourismophobia and showing extremely adverse reactions to incoming visitors [20]. To that end, it can definitely be argued that having community satisfaction as a trigger for a change in the tourism approach is critical in ensuring diligence. To summarize, both variables could prove significant in ascertaining the success of mitigation at any given destination, as the triggering reasons for change can be just as critical as the tools of demarketing that are designed for mitigation. Both of these variables are coded as " 1 " in the cases they are present and " 0 " otherwise.

Government Effectiveness: This variable is used to see the impact that a well-run government has on the implementation of overtourism, combatting efforts and their eventual success. An efficient and committed approach to combating the effects of overtourism would no doubt yield better results compared with the haphazard way some authorities go about implementing such plans, as was the case in Kasane, Botswana [21]. This is also the only variable in the current study that comes from an external data bank compared with the other variables, for which the data originated from previous research. Obviously, this is a factor that is not easy to quantify; therefore, the related data is gathered through Worldwide Governance Indicators (WGI). As a project of the World Bank, the WGI database assesses the capacity of governance for more than two hundred countries across the globe. The indicator that this study uses is focused on analyzing the quality of overall public services, the efficiency and execution of civil services, the excellence of the formulation of regulations and their implementation, the autonomy of civil services when faced with political strain, and the level of commitment shown by the government to all the clauses above [22]. The indicator is measured in several metrics, and the one used for this research is the percentile rank for the chosen governance indicator. The average rank for government effectiveness from this database for the countries featured in this study is 70. Therefore, this number is used as a cutoff point for evaluating the indicator for the destinations. For the cases that come from a country with an above-average score in government effectiveness-that is, above the 70 th percentile- the data are coded as " 1 ", whereas cases that are derived from destinations below that average are coded as " 0 ".

Summary statistics for the variables used in the model are presented in Table 2. Apparently, there is a decent success rate of mitigation amongst cases investigated in the literature (68.3\%). Price-related strategies are surprisingly low (26.6\%) compared with the other members of the $4 P$ club. Barely a quarter seems to care about community satisfaction $(26.6 \%)$, whereas environmental concerns are present in half of the cases. A big chunk of the cases were investigated in the post Rio+20 era, and finally, over half of the cases were published in refereed journals or books.

Table 2. Summary statistics for the variables in the model.

\begin{tabular}{cc}
\hline Variable & Frequency of Data Value "1" \\
\hline Mitigation & 41 of $60(68.3 \%)$ \\
Price & 16 of $60(26.6 \%)$ \\
Place & 35 of $60(58.3 \%)$ \\
Product & 52 of $60(86.6 \%)$ \\
Promotion & 33 of $60(55 \%)$ \\
Post-2012 & 48 of $60(80 \%)$ \\
Refereed & 42 of $60(70 \%)$ \\
Environmental Concern & 30 of $60(50 \%)$ \\
Community Satisfaction & 16 of $60(26.6 \%)$ \\
Government Effectiveness $>70$ & 40 of $60(66.6 \%)$ \\
\hline
\end{tabular}




\section{Results}

\subsection{Logit Analysis}

Running the abovementioned logit regression, where the demarketing tools were the main variables and the other five independent variables were regressed on mitigation of overtourism, the results in Table 3 were reached.

Table 3. Results of the logit model with robust standard errors ${ }^{2}$.

\begin{tabular}{cccccc}
\hline & Coefficient & $\begin{array}{c}\text { Std. } \\
\text { Error }\end{array}$ & $z$ & $p$-Value & Sign. \\
& -0.501021 & 2.06433 & -0.2427 & 0.8082 & \\
Constant & 6.41287 & 2.11973 & 3.025 & 0.0025 & $* * *$ \\
Price & -1.13541 & 1.04864 & -1.083 & 0.2789 & \\
Place & 1.83535 & 1.24982 & 1.468 & 0.1420 & \\
Product & -0.676409 & 0.978164 & -0.6915 & 0.4892 & \\
Promotion & -2.85625 & 1.41688 & -2.016 & 0.0438 & $* *$ \\
Post-2012 & -2.08028 & 1.19474 & -1.741 & 0.0816 & $*$ \\
Refereed & 3.91796 & 1.10952 & 3.531 & 0.0004 & $* * *$ \\
Environmental Concern & 2.80907 & 1.35011 & 2.081 & 0.0375 & $* *$ \\
Community Satisfaction & 3.44465 & 1.26229 & 2.729 & 0.0064 & $* * *$ \\
Government Efficiency $>70$ & 0.683333 & S.D. dependent var & 0.469102 & \\
Mean dependent var & 0.490129 & Adjusted R-squared & 0.223177 & \\
McFadden R-squared & -19.09971 & Akaike criterion & 58.19942 & \\
Log-likelihood & 79.14287 & Hannan-Quinn & 66.39156 & \\
Schwarz criterion & 50 & Likelihood ratio test: & $36.7203[0.0000]$ \\
Number of cases correctly & $(83.3 \%)$ & Chi-square (9) & & \\
predicted' & &
\end{tabular}

2 Legend: ${ }^{*} p<0.05 ;{ }^{* *} p<0.01 ;{ }^{* *} p<0.001$. QML robust standard errors are used. Correlation coefficients for the independent variables are presented in Appendix A Table A2.

The logit estimation predicted 50 out of 60 cases correctly (83.3\%), which is a sign of the accuracy of the analysis. Of the four core independent variables, the $4 P s$, only Price turned out to be a significant predictor of mitigation of overtourism. The other three core independent variables (Place, Product, and Promotion) did not prove to be significant determinants, implying that their implementation in a destination affects the success of mitigation efforts neither negatively nor positively. All five of the supporting independent variables yielded significant results, being effective factors of mitigating overtourism. The coefficients of the variables Post-2012 and Refereed turned out to be significantly negative. They adversely affect the success chances of mitigation of overtourism. Moreover, the two driving force variables (Environmental Concern and Community Satisfaction) as well as Government Effectiveness turned out to be significant predictors that positively affect the dependent variable. Out of all nine independent variables, Price is the one with the highest impact towards mitigation, bearing a coefficient estimate of 6.41 .

\subsection{Interpreting the Coefficients}

The logit regression coefficient estimates displayed in Table 3 are difficult to interpret directly. It requires a mathematical transformation to understand what these coefficients imply. Logit produces a relationship similar to that in linear regression except that now each one-unit change in an independent variable is associated with a change in log odds rather than the direct response. Here, odds equal Prob(event)/Prob(no event). Interpretation of the coefficients is complicated as they relate to changes in log odds rather than the response itself.

To ease the interpretation, probabilities of "event" can be estimated by calculating $\exp (\beta i) /[1+\exp (\beta i)]$ for each explanatory variable. The upper and lower bounds for "event" probabilities are constructed by adding and subtracting two standard errors to and from the coefficient estimates. Consequently, the exponentials of the upper and lower bounds and the mean values are taken to calculate the probabilities. 
For instance, when the coefficient of Price is substituted into the equation, the value of 0.9983 is obtained when all of the other independent variables take the value " 0 ". This value indicates that the application of the Price demarketing tool alone in a destination shows success with an average probability of $99.8 \%$ in reducing overtourism (see Figure 1 for an illustration).

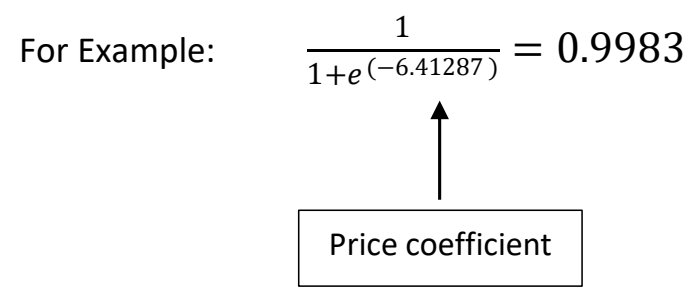

Figure 1. Interpreting the coefficients-an example.

Since beta coefficients provide mean estimates for the effects of the independent variables, a confidence interval could be obtained by determining the lower and upper limits of the beta coefficients. These lower and upper values are calculated with the following formula:

$$
\left.\beta \pm t^{*} \text { (standard error of } \beta\right)
$$

where $\beta$ in this formula represents the coefficient of an independent variable and the $t$ value represents the confidence level. Since a confidence level of 95 percent is preferred in this study, the $t$ value is accepted as 2.013 .

Then, these limit values are substituted in the estimated logit equation one by one. The obtained values also provide us with the probability range that would affect the dependent variable (see Table 4).

Table 4. Estimated probabilities of the mitigation of overtourism.

\begin{tabular}{cccccccc}
\hline & Coefficient & Std. Error & $\begin{array}{c}\text { Coefficient } \\
\text { Lower } \\
\text { Bound }\end{array}$ & $\begin{array}{c}\text { Coefficient } \\
\text { Upper } \\
\text { Bound }\end{array}$ & $\begin{array}{c}\text { Probability } \\
\text { Effect Lower } \\
\text { Bound }\end{array}$ & $\begin{array}{c}\text { Probability } \\
\text { Effect Upper } \\
\text { Bound }\end{array}$ & $\begin{array}{c}\text { Mean } \\
\text { Probability }\end{array}$ \\
\hline Price & 6.4129 & 2.1197 & 2.14585 & 10.67988 & 0.8952 & 0.9999 & 0.99836 \\
Environ. Concern & 3.9179 & 1.1095 & 1.68449 & 6,15142 & 0.8434 & 0.9978 & 0.98050 \\
Comm. Satisf. & 2.8091 & 1.3501 & 0.09129 & 5,52684 & 0.5228 & 0.9960 & 0.94316 \\
GovEff70 & 3.4447 & 1.2623 & 0.90366 & 5.98563 & 0.7117 & 0.9974 & 0.96907 \\
Post-2012 & -2.8562 & 1.4169 & -5.70842 & -0.00407 & 0.0033 & 0.4990 & 0.05435 \\
Refereed & -2.0803 & 1.1947 & -4.48529 & 0.32473 & 0.0111 & 0.5804 & 0.11102 \\
\hline
\end{tabular}

Let us exemplify the Price variable again to understand what the values in Table 4 indicate. The results provide $95 \%$ confidence towards the argument that the implementation of the Price tool in a destination mitigates overtourism with a probability between 89.5 and 99.9 percent (see Table 4, first row).

Higher than $90 \%$ mean probabilities are estimated for Environmental Concern, Community Wellbeing, and Government Effectiveness. On the other hand, the destinations that were investigated in the literature after 2012 and for which investigations were published in refereed sources prove to be less eager to mitigate overtourism, implying less than $50 \%$ mean probabilities.

Insignificant coefficient estimates are not shown in the table. For such coefficients, as in the case for Place, Product, and Promotion, it implies that, when the value of that variable for a destination moves from 0 to 1 , ceteris paribus, the probability of that destination to experience mitigation in overtourism is about 0.5 . 


\subsection{Limitations of the Study}

One of the most important issues in conducting this research is that some studies could not be reviewed due to language barriers. Some destinations were analyzed in reports or articles in their own language, which was a significant hindrance.

Moreover, comparability of the destinations is another issue as a variety of destinations ranging from historical cities and national parks to beaches and wildlife centers was handled in the current study. The success of demarketing would definitely vary depending on the type of destination under investigation. One way to mitigate this difficulty could be grouping similar types of destinations and running separate logit regressions for them; however, in that case, the number of observations in each regression would be highly limited and insufficient.

Another limitation is the inability to examine in detail the process-execution harmony between municipalities and the state. To elaborate a little more, if the municipality implements demarketing strategies to reduce overtourism in the region while the state oppositely implements an incentive policy to increase visits to the same region, this indicates a policy conflict between the state and the municipality. In addition, it would be a big mistake to conclude that the demarketing strategy, which might be successful in the absence of policy conflict, has failed. Considering this situation, government effectiveness is included as an independent variable in the logit regression. Thus, the government effectiveness indicator is intended to ensure the confidence in the preparation and implementation of quality policies and that governments adhere to these policies [22].

Another limitation is that some of the studies related to the subject are theoretical and there is no information about whether the demarketing strategies mentioned in these studies reduce overtourism in real life. Therefore, these studies were not included in our data set. The last limitation that should be mentioned is that it is impossible to be one hundred percent sure of a hundred percent accuracy of the cases in some of the studies. Data were collected from many sources, including peer-reviewed articles, non-refereed articles, and reports. Since peer-reviewed articles are subject to some degree of control and review processes, there could be a publication bias that could arise in non-refereed articles and reports. This issue is tackled through the instrumentation of the variable Refereed in the logit analysis.

\section{Discussion}

While conducting this research, several different regulation examples in terms of price were encountered. For instance, price increases are made on a regular basis to lessen demand and raise revenue in order to repair damage caused by tourists, and price reductions are made during the low season. Some public areas are becoming privatized and now require an entry fee. Real estate values (both rental and purchase of usable area) have risen. Raising prices often has a deterrent effect on people. According to the research of Monroe [23], for some products and services, people often unintentionally set a price in their minds, and if this limit is exceeded, they may sacrifice that product or service. While planning the demarketing, these tendencies of people are taken into consideration. That is why the price strategy might have proven to be successful. Additionally, the same study indicates that price is an impactful deterrent, and our results back up this assertion in the way it shows that the strategies centered around change in pricing provides the most positive feedback as well as proves to be the most effective variable in the mitigation of overtourism. Using price demarketing as a tool for demand and visitor management, many of the studied destinations have achieved favorable outcomes. For instance, in the study of Kainthola et al. [24] about the Taj Mahal, they increased the entrance fee of Taj Mahal in order to reduce the number of visitors, and it worked well to achieve a reduction in overtourism.

The precautions about "place" have not affected the mitigation of overtourism significantly, and this means that the strategies employed, no matter how detailed, were not impactful one way or the other. In the case studies, the changes to "place" were usually 
about making certain changes in the physical area. In general, measures were taken, such as closing some areas to visitor access or restricting the number of visitors to designated spaces. Unfortunately, this made one of the demarketing cornerstones, the place data, null in terms of mitigation impact. No matter what was attempted, be it putting a limit to the accommodation facilities, as was the case in Mallorca [25], making some areas harder to reach and enter or limiting the parking facilities in some cities, it proved insignificant in our analysis of the previously studied destinations. One can make a few inferences from here: these strategies were either not ambitious enough to reduce mitigation or not applied correctly.

According to the results obtained through this study, promotion turned out to be another insignificant demarketing tool against overtourism, which was contradictory to our expectations. Well-executed promotional campaigns should have been proven as an effective mechanism in mitigating overtourism in theory, but as the case studies demonstrate, promotional efforts actually had no discernible effect on mitigation. According to the data gathered for this research, many different strategies were carried out for promotion, but the results are still insignificant in terms of mitigation. One of the good examples of work carried out about promotion campaigns is the case of Amsterdam. As Hall and Wood [6] indicated, according to the statement of the head of the marketing activities of Amsterdam, they have not spared even EUR 1 for marketing of Amsterdam for the last few years. Their main goal is not to attract more people but to expect a higher quality tourist profile. In destinations where overtourism is present, it seems necessary to make a minimum effort in terms of promotion and to attach importance to sustainability in these demarketing campaigns. However, Amsterdam still suffers from an excessive number of visitors.

The results of this study show that product as a demarketing tool is yet another insignificant factor towards the mitigation of overtourism. The findings indicate that the strategies centered on demarketing the "product" have been largely ineffective. An example of restrictions applied for this particular demarketing tool would be the case from Bruges [26]. The Belgian government has stipulated that walking tours in the city can only be made with a guide. For groups of people over a certain number, it was made mandatory to listen to the city tour with audio-restricting gear in order to prevent noise pollution in the area. For those who do not comply with these rules, a fine of over 200 euros was determined. However, the regulations did not help much. Furthermore, we can infer from the results that putting severe restrictions on, strictly monitoring, or even completely stopping some activities did not prove to be a viable and effective solution towards overtourism, although the implementation of the strategies were iffy at best in a good number of case studies.

The results also show that, in the event of environmental concerns playing a large part in the eventual implementation of various demarketing strategies, there is a significant effect on the mitigation of the overtourism. From this, one can gather that, if the underlying reasons of overtourism in the destination are threatening the ecology of the area, more honest and effective solutions towards overtourism have been implemented. This falls in line with the research of Hall [27], which argues that significant environmental concerns have big effects on the community and their willingness to become involved in more sustainable tourism practices. According to previous research [28,29], environmental concerns need to be focused on because humans need to balance human activities and its effects on the environment. In the case of Dubrovnik [30], which focused on waste management, limiting air and noise pollution, and controlling water supply systems are some of the options that should be focused on in order to provide environmental management. It can be seen as a successful example in this aspect.

Due to overtourism, the people living in those regions are also suffering, and their quality of life is declining. Many communities are becoming victims of the negative effects of overpopulation. The findings suggest that, similar to environmental concerns, the happiness of the communities where this is a present concern is a significantly important factor in the mitigation of overtourism. It can be said that "the will of the people" is 
a strong precipitating force in terms of making the authorities act with diligence and commitment when it comes to their strategies to cope with overtourism. A wonderful example is the Kichwa Añangu community [31], who became the driving force for a successful overtourism mitigation strategy in Napo, Ecuador.

With the steps taken in the Rio +20 United Nations Conference on Sustainable Development, it was believed that the promises of commitment made by the attendants of the event towards Agenda 21 and "The Future We Want" would mean a significant improvement towards the mitigation of overtourism going forward, with countries allocating more resources to sustainability issues than ever before. However, the results of the current research suggest that the demarketing efforts that were made after 2012 have resulted in the exact opposite of the expected outcome. This implies that the promises and commitments made in 2012 by the 190+ United Nations member states have not been followed through, and there is a disconnect between the aims of Rio +20 and the actions of the members. The result in which mitigation of overtourism somehow became worse after 2012 does not inspire confidence in the ability and commitment of the world's governments towards implementing better, more sustainable tourism practices in the future. With the increasing impact of overtourism on countless destinations across the globe and the steadily rising outcry for more sustainable practices to ensure an inheritable world for upcoming generations, amendments to Agenda 21 and more strict (and enforced) policies by the United Nations towards this issue might be necessary in order to accomplish better mitigation.

The results also show that the refereed case studies represented strategies that were significantly unsuccessful in the mitigation of overtourism. Refereed studies are almost always the ones that are more meticulous in their approach in comparison with those that are not refereed, and they are also fact-checked or peer-reviewed. Hence, this result implies that the more in-depth a study is, the less likely it is to uncover a success story for detecting a positive effect on overtourism. Unfortunately, it is entirely possible that the authorities or representatives of some destinations might have falsified numbers and information in order to present a more favorable view to the rest of the world, which should be kept in mind.

One of the crucial explanatory variables in this particular research is Government Effectiveness. It is important to find out if the quality of regulations put forward by the destinations are sufficient and if these regulations are implemented with the correct amount of diligence, which would make a significant difference in the mitigation of overtourism. Perhaps unsurprisingly, the results of the research indicate that destinations that benefit from above average levels of Government Effectiveness are significantly better in mitigation compared with their counterparts who do not have the same characteristics in terms of the perceptions regarding, e.g., the quality of public services, the quality of the civil service and the degree of its independence from political pressures, the quality of policy formulation and implementation, and the credibility of the government's commitment to such policies. The implication of this particular result is quite obvious, as it points out a significant increase in overtourism mitigation success if the implemented tools and the present triggering concerns are backed by an effective government that go the extra mile to ensure that the plans are implemented correctly and efficiently. Therefore, one can safely say that the support of an effective government is of great importance when a destination tries to utilize various strategies against overtourism. Unfortunately, the success of this variable also means that countries with less effective governments struggle a lot more when trying to mitigate overtourism as that will be yet another hurdle they will have to overcome against an already troublesome issue. All in all, the implication is that better government effectiveness-stronger commitments, better implementation, and a more diligent approach to strategies_-will result in demarketing efforts yielding successful results. 


\section{Conclusions}

Overtourism is a major threat to sustainability that is growing day by day. Alternative approaches proposed by the firms and entrepreneurs within the tourism industry are not likely to get rid of the negative connotations of overtourism that occur when one confronts the reality of our planet having a certain limit to how much growth it can handle. Amongst the countless solutions proposed by the academic communities and experts at large, demarketing seems to have slipped under the cracks as a viable alternative with a lot of potential, though that potential needs to be realized through honest efforts and strong commitments from all stakeholders involved in the process. Demarketing as a whole is an interesting concept with many upsides in any sector in which it might be implemented, but the consumerist approach of modern day entities clash strongly with it. Hence, there needs to be an in-depth change in consumption patterns before large-scale implementations of the idea are possible in any sector. The concept is oddly suited to tourism though, with the increasing need to slow down visitor growth in many popular destinations. Considering the lack of strategies that could counter the effects of overtourism, demarketing has the potential to emerge as a very strong mitigator. Quite a few strategies on handling excessive visitor numbers are used reactively, only when problems start occurring in tourism destinations. If demarketing is incorporated into the classical marketing mix as a proactive method of dealing with any future issues in terms of sustainability, the tourism industry could undercut many problems without having to panic and implement over-the-top strategies.

A suggestion on further research into this topic would be a more in-depth look into the relationships between governments and municipalities of destinations as well as the overlying laws and regulations that countries possess and the related policies they implement. They can provide nothing but benefits for a study of this type, as they are critical in the formulation and implementation of the strategies. Studies that feature less destinations but a much more in-depth analysis into the practical aspects and overall implementation of demarketing can also provide more detailed results as to why demarketing works-or does not work.

As for the tools of the concept, which are categorized under the 4Ps for this study, the results show that only price is a significant factor in terms of mitigation of overtourism. These tools are rarely what one can consider mutually exclusive, and a touristic destination can make use of multiple tools at the same time or can even alternate between effective demarketing tools over time, as the needs of the destinations change. The results paint a rather straightforward picture, and while it is a bit disheartening for the results to reflect the cliché thinking of "Money makes the world turn", the effectiveness of price manipulation in terms of manipulating consumers is undeniable. On the other hand, it seems that place, product, and promotion are not effective tools to help mitigate overtourism-or nobody has managed to make them work at an acceptable level so far as evidence from the related literature prevails. The historic cities of Amsterdam, Bruges, Dublin, London, Mallorca, Prague, Valencia, and Vienna are outstanding examples of the failure to combat overtourism despite accommodating one or more demarketing tools in order to manage mass tourism.

All in all, the results of this study show that price as a demarketing tool is the only worthwhile one when a destination tries to undercut overtourism through demarketing strategies. There are other factors that significantly enhance the chances of success, such as government effectiveness, and the presence of environmental and community satisfaction concerns triggering factors of change. These imply that the cause for change and implementation of demarketing can be just as important as the tools used and the end results. It is also not that big of a leap in logic to assume that demarketing can potentially be applied to any destination suffering from overtourism; however, the choice of the demarketing tools should be made elaborately. The reasons why specific demarketing tools, other than price, fail to mitigate overtourism need to be studied. Moreover, any strategy in this regard needs to be implemented with the right amount of commitment, a lot of stakeholder involvement, 
diligent processes, meticulous planning, and support from an effective government. This is a concept with very high potential for the future, and a lot can be achieved if the people involved can spare the necessary effort.

Author Contributions: Conceptualization, S.A., U.G., H.Y., P.A. and İ.E.; methodology, S.A; software, S.A. and U.G.; validation, S.A., U.G., H.Y., P.A. and İ.E.; formal analysis, S.A., U.G., H.Y., P.A. and İ.E.; investigation, U.G., H.Y., P.A. and İ.E.; resources, U.G., H.Y., P.A. and İ.E.; data curation, S.A., U.G., H.Y., P.A. and İ.E.; writing-original draft preparation, U.G., H.Y., P.A. and İ.E.; writing-review and editing, S.A.; visualization, S.A., U.G., H.Y., P.A. and İ.E.; supervision, S.A. All authors have read and agreed to the published version of the manuscript.

Funding: This research received no external funding.

Institutional Review Board Statement: Not applicable.

Informed Consent Statement: Not applicable.

Data Availability Statement: Data supporting the reported results can be found in Appendix A. Further detail is available upon request from the authors.

Acknowledgments: Valuable article suggestions and comments from Evinç Doğan as well as the anonymous reviewer(s) are acknowledged. Any remaining errors reside solely with the authors.

Conflicts of Interest: The authors declare no conflict of interest.

\section{Appendix A}

Table A1. Case studies and destinations in the data set.

\begin{tabular}{|c|c|}
\hline STUDY & DESTINATION \\
\hline Soliman (2010) [2] & Giza (Egypt) \\
\hline \multirow{3}{*}{ Bradley \& Blythe (2013) [5] } & The UK countryside \\
\hline & St Kilda (UK) \\
\hline & London (UK) \\
\hline Clements (1989) [8] & Cyprus \\
\hline Nyaupane \& Timothy (2010) [15] & Bhutan \\
\hline Binter et al. (2016) [16] & Bled (Slovenia) \\
\hline Carlsen \& Ali-Knight (2004) [17] & Napa Valley (USA) \\
\hline \multirow{3}{*}{ Sancán Chonillo \& Sánchez Álvarez (2017) [19] } & Playa de Las Catedrales (Spain) \\
\hline & Islas Cíes (Spain) \\
\hline & Torres del Paine (Chile) \\
\hline Martins (2018) [20] & Barcelona (Spain) \\
\hline \multirow{5}{*}{ Weber et al. (2017) [21] } & Baku (Azerbaijan) \\
\hline & Cozumel (Mexico) \\
\hline & Kasane (Botswana) \\
\hline & Lombok (Indonesia) \\
\hline & Muskoka (Canada) \\
\hline Kainthola et al. (2021) [24] & Taj Mahal (India) \\
\hline Blázquez-Salom et al. (2019) [25] & $\begin{array}{l}\text { Valencia (Spain) } \\
\text { Mallorca (Spain) }\end{array}$ \\
\hline
\end{tabular}


Table A1. Cont.

\begin{tabular}{|c|c|}
\hline STUDY & DESTINATION \\
\hline \multirow{14}{*}{ Peeters et al. (2021) [26] } & Bagan (Myanmar) \\
\hline & Bruges Historic Centre (Belgium) \\
\hline & Echternach (Luxembourg) \\
\hline & Juist Island (Germany) \\
\hline & Reykjavik (Iceland) \\
\hline & Riga (Latvia) \\
\hline & Stockholm (Sweden) \\
\hline & Vilnius (Lithuania) \\
\hline & Dublin (Ireland) \\
\hline & Yellowstone (USA) \\
\hline & Salzburg Historical Centre (Austria) \\
\hline & Tallinn Old Town (Estonia) \\
\hline & Valletta (Malta) \\
\hline & Machu Picchu (Peru) \\
\hline Camatti et al. (2020) [30] & Dubrovnik (Croatia) \\
\hline Renkert (2019) [31] & $\begin{array}{l}\text { Kichwa Añangu community } \\
\text { Napo Wildlife Center } \\
\text { Yasuni National Park (Ecuador) }\end{array}$ \\
\hline \multirow{3}{*}{ Beeton \& Benfield (2002) [32] } & Milan (Italy) \\
\hline & Kent (UK) \\
\hline & Victoria (Australia) \\
\hline Fernández Vicente (2019) [33] & Bali (Indonesia) \\
\hline Oklevik et al. (2019) [34] & Norway \\
\hline Drugova et al. (2020) [35] & $\begin{array}{c}\text { Bryce Canyon National Park } \\
\text { Zion National Park } \\
\text { Glen Canyon National Recreation Area } \\
\text { Arches National Park (USA) }\end{array}$ \\
\hline Magalhães et al. (2017) [36] & Rainbow Bridge National Monument (USA) \\
\hline Groff (1998) [37] & Utah (USA) \\
\hline Armstrong \& Kern (2011) [38] & Blue Mountains National Park (Australia) \\
\hline Eliasson \& Velasco (2018) [39] & Amsterdam (Netherlands) \\
\hline \multirow{2}{*}{ Andriotis (2018) [40] } & Fernando de Noronha (Brazil) \\
\hline & Mount Athos (Greece) \\
\hline Thaha (2020) [41] & Vienna (Austria) \\
\hline Namberger et al. (2019) [42] & Munich (Germany) \\
\hline \multirow{3}{*}{ Hastings (2014) [43] } & Venice and its Lagoon (Italy) \\
\hline & $\begin{array}{l}\text { Archaeological Areas of Pompeii, } \\
\text { Herculaneum, and Torre Annunziata (Italy) }\end{array}$ \\
\hline & Valcamonica (Italy) \\
\hline Burgin \& Hardiman (2014) [44] & $\begin{array}{c}\text { Greater Blue Mountains } \\
\text { World Heritage Area (Australia) }\end{array}$ \\
\hline \multirow{2}{*}{ Wearing \& Neil (1999) [45] } & Catlins area (New Zealand) \\
\hline & South Pentecost (Vanuatu) \\
\hline
\end{tabular}


Table A1. Cont.

\begin{tabular}{cc}
\hline STUDY & DESTINATION \\
\hline & Besalú (Spain) \\
Arias-Sans \& Milano (2019) [46] & Hangzhou (China) \\
\cline { 2 - 2 } & Prague (Czech Republic) \\
\hline Miller \& Twining-Ward (2006) [47] & Samoa \\
\hline
\end{tabular}

Table A2. Correlation coefficients, using the observations $1-60(5 \%$ critical value (two-tailed $)=0.2542$ for $n=60$ ).

\begin{tabular}{cccccc}
\hline Price & Place & Product & Promotion & Post-2012 & \\
\hline 1.0000 & 0.2039 & 0.0148 & 0.1667 & -0.2638 & Price \\
& 1.0000 & 0.0663 & -0.0849 & 0.1690 & Place \\
& 1.0000 & -0.3548 & -0.0735 & Product \\
& & 1.0000 & -0.0335 & Promotion \\
& & & 1.0000 & Post-2012 \\
& & & & \\
& & & Comm. & GovEff70 & Price \\
& & Environ. & Satisf. & -0.1333 & Place \\
& & & 0.3182 & -0.0956 & Product \\
& -0.1480 & 0.1508 & 0.0510 & -0.1733 & Promotion \\
& 0.1498 & 0.0000 & 0.0148 & 0.1421 & Post-2012 \\
& -0.2364 & 0.0335 & 0.0909 & 0.0884 & Refereed \\
& -0.1667 & -0.0754 & 0.1543 & Environ. Concern \\
& -0.0727 & 0.3948 & -0.1414 & Comm. Satisf. \\
& 1.0000 & & 0.2261 & 0.0267 & GovEff70 \\
\hline
\end{tabular}

\section{References}

1. Dodds, R.; Butler, R. The phenomena of overtourism: A review. Int. J. Tour. Cities 2019, 5, 519-528. [CrossRef]

2. Soliman, D.M. Managing visitors via demarketing in the Egyptian world heritage site: Giza pyramids. J. Assoc. Arab. Univ. Tour. Hosp. 2010, 7, 15-20.

3. Butler, R.W. Sustainable tourism: A state-of-the-art review. Tour. Geogr. 1999, 1, 7-25. [CrossRef]

4. Kotler, P.; Levy, S.J. Demarketing, yes, demarketing. Harv. Bus. Rev. 1971, 79, 74-80.

5. Bradley, N.; Blythe, J. (Eds.) Demarketing; Routledge: London, UK, 2013.

6. Hall, C.M.; Wood, K.J. Demarketing tourism for sustainability: Degrowing tourism or moving the deckchairs on the titanic? Sustainability 2021, 13, 1585. [CrossRef]

7. Olokesusi, F.; Agboola, G.; Aina, C.; Ajayi, O. Evolution of Demarketing in the Tourism Industry and Implications for Sustainability. Int. J. Innov. Sci. Res. Technol. 2019, 4, 625-630.

8. Clements, M.A. Selecting tourist traffic by demarketing. Tour. Manag. 1989, 10, 89-94. [CrossRef]

9. Gerstner, E.; Hess, J.; Chu, W. Demarketing as a differentiation strategy. Mark. Lett. 1993, 4, 49-57. [CrossRef]

10. Beeton, S.; Pinge, I. Casting the holiday dice: Demarketing gambling to encourage local tourism. Curr. Issues Tour. 2003, 6, 309-322. [CrossRef]

11. Medway, D.; Warnaby, G.; Dharni, S. Demarketing places: Rationales and strategies. J. Mark. Manag. 2010, 27, 124-142. [CrossRef]

12. Öztürk, Y. Turistik Destinasyonlarda Talep Yönetimi ve Demarketing Uygulamaları. Türk Tur. Araştırmaları Derg. 2020, 4, 746-757. [CrossRef]

13. Suh, M.; Ahn, J.; Rho, T. A study on the relationship demarketing and customers' relationship behaviors. J. Mark. Manag. Res. 2009, 15, 21-55.

14. Kleinbaum, D.G. Logistic Regression; Springer: Berlin/Heidelberg, Germany, 1994.

15. Nyaupane, G.P.; Timothy, D.J. Power, regionalism and tourism policy in Bhutan. Ann. Tour. Res. 2010, 37, 969-988. [CrossRef]

16. Binter, U.; Ferjan, M.; Neves, J.V. Marketing Mix and Tourism Destination Image: The Study of Destination Bled, Slovenia. Organizacija 2016, 49, 209-223. [CrossRef]

17. Carlsen, J.; Ali-Knight, J. Managing wine tourism through demarketing: The case of Napa Valley, California. Int. Wine Tour. Res. 2004, 15, 266. 
18. Rothstein, H.R.; Sutton, A.J.; Borenstein, M. Publication bias in meta-analysis. In Publication Bias in Meta-Analysis: Prevention, Assessment and Adjustments; John Wiley \& Sons, Ltd.: Chichester, UK, 2005; pp. 1-7.

19. Sancán Chonillo, J.; Sánchez Álvarez, A. Estrategias de Desmarketing para Atenuar la Saturación Existente en el Centro de Recreación Isla Santay. Ph.D. Dissertation, Escuela Superior Politecnica del Litoral, Guayaquil, Ecuador, 2017.

20. Martins, M. Tourism planning and tourismphobia: An analysis of the strategic tourism plan of Barcelona 2010-2015. J. Tour. Herit. Serv. Mark. 2018, 4, 3-7.

21. Weber, F.; Stettler, J.; Priskin, J.; Rosenberg-Taufer, B.; Ponnapureddy, S.; Fux, S.; Barth, M. Tourism Destinations under Pressure: Challenges and Innovative Solutions; Lucerne University of Applied Sciences and Arts, Institute of Tourism ITW: Lucerna, Switzerland, 2017.

22. Kaufmann, D.; Kraay, A.; Mastruzzi, M. The Worldwide Governance Indicators: Methodology and Analytical Issues. Hague J. Rule Law 2011, 3, 220-246. [CrossRef]

23. Monroe, K.B. Buyers' subjective perceptions of price. J. Mark. Res. 1973, 10, 70-80.

24. Kainthola, S.; Tiwari, P.; Chowdhary, N.R. Tourist Guides' Perspectives of Demarketing the Taj Mahal. Int. J. Tour Guid. Res. 2021, 2,4 .

25. Blázquez-Salom, M.; Blanco-Romero, A.; Vera-Rebollo, F.; Ivars-Baidal, J. Territorial tourism planning in Spain: From boosterism to tourism degrowth? J. Sustain. Tour. 2019, 27, 1764-1785. [CrossRef]

26. Peeters, P.; Gössling, S.; Klijs, J.; Milano, C.; Novelli, M.; Dijkmans, C.; Eijgelaar, E.; Hartman, S.; Heslinga, J.; Isaac, R.; et al. Research for TRAN Committee-Overtourism: Impact and Possible Policy Responses; European Parliament, Policy Department for Structural and Cohesion Policies: Brussels, Belgium, 2018.

27. Hall, C.M. Degrowing tourism: Décroissance, sustainable consumption and steady-state tourism. Anatolia 2009, 20 , 46-61. [CrossRef]

28. Papageorgiou, K.; Brotherton, I. A management planning framework based on ecological, perceptual and economic carrying capacity: The case study of Vikos-Aoos National Park, Greece. J. Environ. Manag. 1999, 56, 271-284. [CrossRef]

29. Zacarias, D.A.; Williams, A.T.; Newton, A. Recreation carrying capacity estimations to support beach management at Praia de Faro, Portugal. Appl. Geogr. 2011, 31, 1075-1081. [CrossRef]

30. Camatti, N.; Bertocchi, D.; Carić, H.; van der Borg, J. A digital response system to mitigate overtourism: The case of Dubrovnik. J. Travel Tour. Mark. 2020, 37, 887-901. [CrossRef]

31. Renkert, S.R. Community-owned tourism and degrowth: A case study in the Kichwa Anangu community. J. Sustain. Tour. 2019, 27, 1893-1908. [CrossRef]

32. Beeton, S.; Benfield, R. Demand control: The case for demarketing as a visitor and environmental management tool. J. Sustain. Tour. 2002, 10, 497-513. [CrossRef]

33. Vicente, F.G. Desmarketing de destinos turísticos: Estado de la cuestión, antecedentes y posible aplicación al caso de Donostia. 2019. Available online: https:/ / addi.ehu.es/handle/10810/33154 (accessed on 27 August 2021).

34. Oklevik, O.; Gössling, S.; Hall, C.M.; Steen Jacobsen, J.K.; Grøtte, I.P.; McCabe, S. Overtourism, optimisation, and destination performance indicators: A case study of activities in Fjord Norway. J. Sustain. Tour. 2019, 27, 1804-1824. [CrossRef]

35. Drugova, T.; Kim, M.K.; Jakus, P.M. Marketing, congestion, and demarketing in Utah's National Parks. Tour. Econ. 2020, 9 , 9722. [CrossRef]

36. Magalhães, M.J.; de Magalhães, S.T.; Rodrigues, C.; Marques, S. Acceptance criteria in a Promotional Tourism Demarketing Plan. Procedia Comput. Sci. 2017, 121, 934-939. [CrossRef]

37. Groff, C. Demarketing in park and recreation management. Manag. Leis. 1998, 3, 128-135. [CrossRef]

38. Armstrong, E.K.; Kern, C.L. Demarketing manages visitor demand in the Blue Mountains National Park. J. Ecotourism 2011, 10, 21-37. [CrossRef]

39. Eliasson, E.; Velasco, K. Coping with Overtourism: Redirecting Tourism Consumption through Social Media and the Internet; University of Gothenburg: Gothenburg, Sweden, 2018.

40. Andriotis, K. Degrowth in Tourism: Conceptual, Theoretical and Philosophical Issues; CABI: Wallingford, UK; Boston, MA, USA, 2018.

41. Thaha, M. Hotel chains response to highly visited urban tourist destinations: The case of Vienna. Master Thesis, Department of Tourism and Service Management, Modul University Vienna, Vienna, Austria, 2020.

42. Namberger, P.; Jackisch, S.; Schmude, J.; Karl, M. Overcrowding, Overtourism and Local Level Disturbance: How much Can Munich Handle? Tour. Plan. Dev. 2019, 16, 452-472. [CrossRef]

43. Hastings, D.L. Combating Visitor Pressure: Impact of Tourism on the Conservation of World Heritage Sites; University of Washington: Washington, DC, USA, 2014.

44. Burgin, S.; Hardiman, N. Unintended de-marketing manages visitor demand in Greater Blue Mountains World Heritage Area. In Proceedings of the 7th International Conference on Monitoring and Management of Visitors in Recreational and Protected Areas; Tallinn University, Institute of Health Sciences and Sports: Tallin, Estonia, 2014. [CrossRef]

45. Wearing, S.; Neil, J. Ecotourism: Impacts, Potentials and Possibilities; Butterworth-Heinemann: Oxford, UK, 1999.

46. Arias-Sans, A.; Milano, C. Case Studies. In "Overtourism"?-Understanding and Managing Urban Tourism Growth beyond Perceptions; UNWTO: Madrid, Spain, 2019. [CrossRef]

47. Miller, G.; Twining-Ward, L. Monitoring as an approach to sustainable tourism. In Tourism Management Dynamics: Trends, Management and Tools; Routledge: London, UK, 2006; pp. 51-57. 